Marta MACIEJEWSKA, Monika KARDACH, Marta GALANT, Paweł FUĆ Poznan University of Technology (Politechnika Poznańska)

\title{
THE RISK OF HAZARDS ANALYSIS IN UNMANNED AERIAL VEHICLE FLIGHT
}

\author{
Analiza ryzyka zagrożeń w locie bezzałogowym \\ statkiem powietrznym
}

\begin{abstract}
Along with development Commercial Air Transport were observed increase popularity of general aviation, include RPAS (Remotely Piloted Aircraft System). In manned air transport through years created a lot of standards and regulations. For still developing RPAS not created any official rules came from ICAO. This article is a trial to arranged available and commonly using methods risk management hazard to RPAS area. Prepared a list of 72 questions about the hazard sources occurring in the analyzed area. The answers allow to identify 45 sources of hazard. Based on them, 18 hazards were identified. Guided by the ideas and good practices of manned aviation, it is necessary to harmonize legal regulations concerning safety management in unmanned flights.
\end{abstract}

Keywords: risk of hazards management, remotely piloted aircraft system, hazard sources

Streszczenie: Wraz z rozwojem lotnictwa komercyjnego, obserwuje się również rosnaca popularność lotnictwa ogólnego, w tym Bezzałogowych Statków Powietrznych (BSP). $W$ załogowym transporcie lotniczym przez lata powstało wiele norm i przepisów prawnych dotyczacych zarzadzania ryzykiem. Dla wciąz rozwijajacych się BSP nie stworzono jeszcze, na tym obszarze zarzadzania zaawansowanych zasad. Niniejszy artkut jest, więc próba adaptacji dostepnych i powszechnie wykorzystywanych metod zarzadzania ryzykiem zagrożeń do obszaru BSP.Opracowano listę 72 pytań o występowanie źródet zagrożeń $w$ badanym obszarze analiz. Odpowiedzi pozwolity na rozpoznanie 45 źródeł zagrożeń. $\mathrm{Na}$ ich podstawie zidentyfikowano 18 zagrożen. Kierując się ideami i dobrymi praktykami lotnictwa zalogowego, należy doprowadzić do ujednolicenia unormowań prawnych dotyczacych zarzadzania bezpieczeństwem $w$ lotach bezzałogowych.

Słowa kluczowe: zarządzanie ryzykiem zagrożeń, bezzałogowe statki powietrzne, źródła zagrożeń 


\section{Introduction}

Aviation is the best procedurally organized branch of transport. Procedures and research lead in this domain make possible travel in short time to different part of the world. Along with development Commercial Air Transport were observed increase popularity of general aviation, include RPAS (Remotely Piloted Aircraft System), which are defined as an aircraft that is flown from a remote location without a pilot located in the aircraft itself [18]. During progress RPAS there was a necessity to lead research to provide acceptable level of risk. Nowadays is trend aimed to limited mistakes related with human factor. In response to this arise new and more specific standards and safety systems. According to ICAO (International Civil Aviation Organization) requirements there are three strategy of risk management: reactive, preventive and proactive method [8]. The first method carry to events, which have already taken, like incidents and accidents. Preventive method actively recognized risk through analysis organized actions. Last method is proactive, which value system action in real time during ordinary operations to define potencional hazards [14]. In this article focused on formulated hazards in chosen area, which is one of the key stage of process risk analysis. In manned air transport through years created a lots of standards and regulations [8, 19]. For still developing RPAS not created any official rules came from ICAO.

Only available form regulations for RPAS area described JARUS (Joint Authorities for Rulemaking on Unmanned Systems). Information contained there have only advisory character, not legal/lawful. This article is a trial to arranged available and commonly using methods risk management hazard to RPAS area.

\section{Risk management algorithm}

Risk is defined as combination of probability activated hazards in unwanted event and due to, in case of that, damage [1]. To achieved acceptable level of risk should be used risk management algorithm (fig. 1). Algorithm divided for two main parts: risk assessment and response to risk. The first part was risk analysis and risk evaluation. To achieved analysis should recognized analysis area, hazard sources and formulated hazards. First step at risk management algorithm is recognized analysis area, it's understood as identification or description. Identification analysis area is equivalent to collect information necessary to take risk hazards assessment including all environment factors, which could have impact on generation hazard sources. After recognized analysis area accede to identificated hazard sources. It can be executed with using checklist. Compilation of control questions was 
performed based on analysis of collected information. The results of performed control list should be establishment that in analysis area occurred factors, which could be define as hazard sources. After recognized analysis area next came process of identification hazard sources. According to SMM (Safety Management Manual) it's formulated, documented action based on reactive, proactive and preventive methods collecting safety data [4, 7]. The most appropriate it's predictable methodology, which is known also as predictive approach.

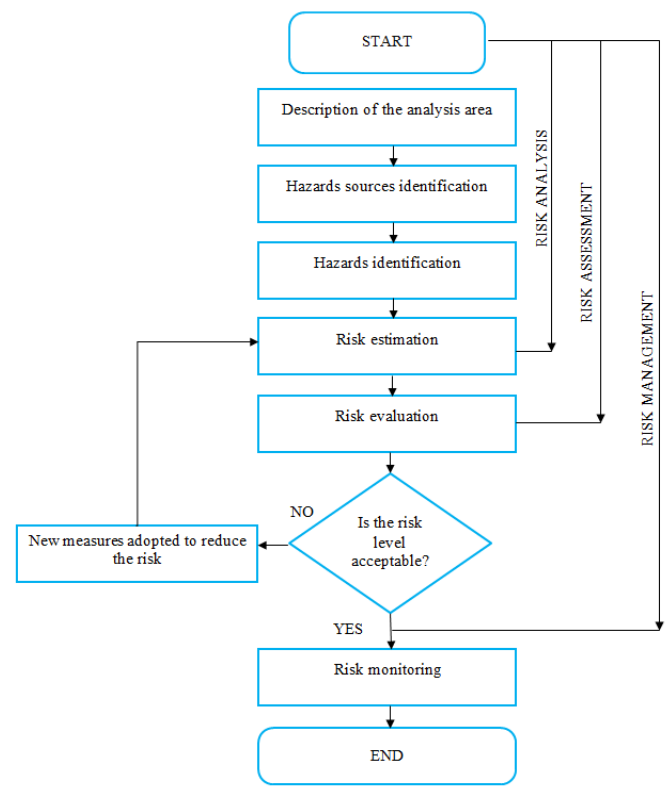

Fig. 1. Risk management algorithm, own elaboration, based on $[4,9,11,12,17]$

This methodology include action related with predicted future events and trends. Based on current and historical episodes there are searching relations, which could predicted future hazard sources. There are many models, which concern on safety flight theory, include: Singleton's theory, C. O. Miller's theory, 5M theory, Model SHEL(L), B. F. Łomotow's nad K. K. Płatnow's theory, James Reason's Theory, HFACS - System and classification impact of human factor. Regardless for diversity listed theory, constantly human factor is the key element, without the system could not act and arise. For example in SHEL Hawkin's model (S software, H - hardware, E - environment, L - liveware) from 1975 human was presented as critical element of human - human, human - environment, human technic, human - automatic, human systems or as the most flexible element, which 
can interfere in each part of system. It's from human, in big step, depend, that flight operation will end succeed. SHELL model's is concept tool used to analyzed interaction of various system components. Schematic diagram SHELL model's is present on fig. 2. This model emphasized on individually and human contact points with other system ingredients and characteristic. The human factor (L) take central position in model. There are connection with every factor $(\mathrm{S}, \mathrm{H}, \mathrm{E})$ and otherwise was added one additionally element $-\mathrm{L}$. This element described, that there are disharmony also on human factor - human factor contact points. Matching factor to other elements should state about efficient system work as whole $[3,4,6,13]$. Due to the complexity of risk management process, in this article focused on action related with risk analysis, to be more specific, was used first three steps of risk management algorithm. In the future this article will be base to further considerations on risk assessment.

\section{Implementation selected steps of the risk assessment algorithm}

\subsection{Description of the area of analysis}

Identification of the area of analysis is a key step to the risk assessment algorithm. The area should be defined as generally as it can be universal and as thoroughly to enable a clear results' interpretation. Unmanned Aerial Vehicle Operation in Visual Line of Sight in uncontrolled airspace of FIR Warsaw on the green fields of large city suburbs (Poznań in this case) was chosen as the area of the analysis (fig. 2). At the distance of several hundred meters, there is a border of Controlled Zone. Above the considered area there is a Terminal Maneuvering Area (TMA). Up to a radius of several kilometers, there are railroad tracks, highway and airport.

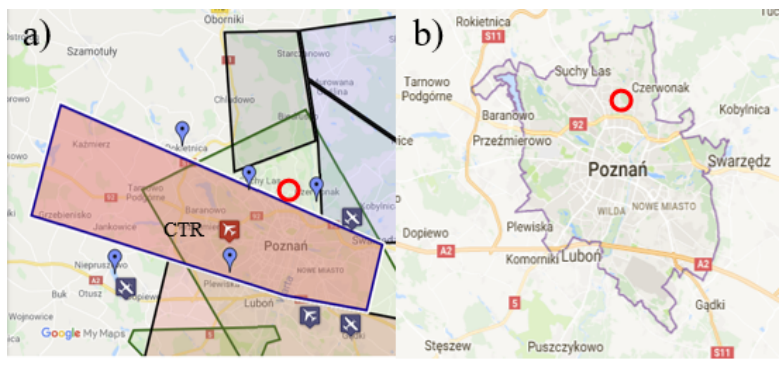

Fig. 2. The area of the analysis (red circle symbolizes borders of the area) a) The map of the area with airspace structure, b) The area on Poznań map 
The risk analysis will be based on the planned flight operation. Unmanned Aerial Vehicle chosen to carry out the operation is a quadrocoptrer (UAV with 4 brushless electric motors) weighting $1.2 \mathrm{~kg}$ and approximated flight time -20 minutes. It has a Return to Home option. Its' range stays up to $100 \mathrm{~m}$ and maximum height of flight reaches $5000 \mathrm{~m}$ a.s.l and the speed up to $10 \mathrm{~m}$ per s. It has got a GPS and accelerometer. It is assumed that UAV does not have enough sensors to overcome all the potential obstacles. It doesn't have a auto-hover function allowing for stable hanging in one position in the case of releasing sticks. It's not possible to start and land fully automatically and to set the "safety flight borders". Due to the fact that UAV can not avoid obstacles, setting the appropriate flight attitude when setting RTH is necessary. RTH won't work if the GPS signal is to weak. In the UAV there are three flight modes available: $\mathrm{P}$ - positioning based on GPS, A Altitude based on barometer parameters and $\mathrm{F}$ - Function intelligent orientation UAV. Modes can be changed by a switch in controller. The controller allows to send a signal up to $1 \mathrm{~km}$. The best solution is when the antenna of the controller are positioned 45 degrees from one another. UAV is powered by lithium-polymer battery performance $4200 \mathrm{mAh}$. Use in case of low temperatures $\left(<10^{\circ} \mathrm{C}\right)$ is not recommended. The temperature of the battery should be higher than $5^{\circ} \mathrm{C}$. The operator is a man without special allowance, over 18 years old with a child. Sightseeing photos for private use and familiarize the child with new technologies are the purpose of the flight.

\subsection{Process of identification hazard sources and hazards formulation}

For implementation hazard sources identification should connect proactive, reactive and preventive methodology. Based on all three methodology extracted sources, which can be useful at identification hazard sources process.

The most frequently used method to identify possible sources of threats is the checklist procedure [4]. This method is one of the most formalized and also most reliable procedure. Preparation of this checklist is proceeded by another one, which is a "brain storm". This allow to fined particularly important hazard sources. Creation of checklists, information about sources of threats, in a given area and their type, is taken into account. To created check list about identification hazard sources, the analysis area was divided to five groups, according to SHELL model's, which was described in point 2: $\mathrm{S}$ - hazard sources concern on procedures, $\mathrm{H}$ hazard sources concern on RPAS, E - hazard sources related with environment, $\mathrm{L}_{\mathrm{A}}-$ hazard sources concern on RPAS operator, $\mathrm{L}_{B}-$ other. 


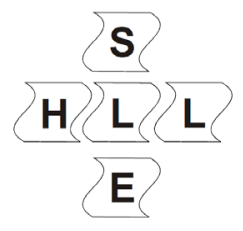

Fig. 3. Schematic diagram SHEL(L) model's $[2,4,6]$

To create a checklist about the occurrence of hazard sources in the analyzed area (tab. 1) were used, among others Airspace Use Plan (AUP) [20], Aeronautical Information Publication (AIP) [16] and instruction of selected RPAS. The next step after the check list about hazard sources in the area of tests is to answer the questions on the list above, by mark the right column ("yes", or "no"). Among the checkboxes, there are shaded "critical fields". If the answer mark coincides with the shaded field it may suggest occurrence of the hazard source. The succeeding step is to identify hazard sources based on separation of the answers covering "critical fields".

Table 1

Fragments of checklist of questions about the occurrence of hazard sources in the analyzed flight along with the answers provided

\begin{tabular}{|c|c|c|c|}
\hline Mark & Question & YES & NO \\
\hline \multicolumn{4}{|c|}{1 group of questions - environment conditions } \\
\hline E. 1. & $\begin{array}{l}\text { Is there a possibility that there are high point infrastructure } \\
\text { facilities near the place of the flight? }\end{array}$ & $\mathrm{X}$ & \\
\hline E. 2. & $\begin{array}{l}\text { Is it possible that the operator will not notice the elements of the } \\
\text { line infrastructure? }\end{array}$ & $\mathrm{X}$ & \\
\hline E. 4. & Is there a possibility of sudden strong gusts of wind? & $\mathrm{X}$ & \\
\hline E. 6. & $\begin{array}{l}\text { Is there a possibility that there is a high-traffic airport in the } \\
\text { immediate vicinity? }\end{array}$ & $\mathrm{X}$ & \\
\hline E. 10. & Is it possible that the flight is performed at night? & & $\mathrm{X}$ \\
\hline E. 14. & Is there a possibility of negative temperatures? & & $\mathrm{X}$ \\
\hline \multicolumn{4}{|c|}{$\begin{array}{l}\ldots \\
2 \text { group of questions }- \text { regarding BSP }\end{array}$} \\
\hline H. 5. & Is there a possibility that the controller is charged? & $\mathrm{X}$ & \\
\hline H. 9. & $\begin{array}{l}\text { Is there a possibility that there are cavities on the surface of the } \\
\text { propeller? }\end{array}$ & $\mathrm{X}$ & \\
\hline \multicolumn{4}{|c|}{$\ldots$} \\
\hline \multicolumn{4}{|c|}{3 group of questions - BSP operator } \\
\hline $\mathrm{L}_{\mathrm{A}} .2$. & Is it possible that the BSP operator is feeling bad? & $\mathrm{X}$ & \\
\hline LA. 5. & $\begin{array}{l}\text { Is it possible that the operator does not know the structure of the } \\
\text { airspace? }\end{array}$ & $\mathrm{X}$ & \\
\hline
\end{tabular}


table 1 cont.

\begin{tabular}{|c|c|c|c|}
\hline LA. 6. & $\begin{array}{l}\text { Is it possible that the operator has not read the operating } \\
\text { instructions? }\end{array}$ & $\mathrm{X}$ & \\
\hline LA. 14. & Is it possible that the operator did not calibrate the GPS? & $\mathrm{X}$ & \\
\hline LA. 19. & $\begin{array}{l}\text { Is there a possibility that the operator will ignore the low battery } \\
\text { warning? }\end{array}$ & $\mathrm{X}$ & \\
\hline LA. 22. & $\begin{array}{l}\text { Is there any assurance that the operator will first turn on the } \\
\text { transmitter and then the BSP? }\end{array}$ & & $\mathrm{X}$ \\
\hline \multicolumn{4}{|c|}{ 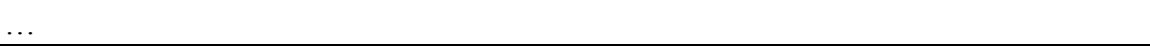 } \\
\hline \multicolumn{4}{|c|}{4 group of questions - other related to man } \\
\hline Lв. 3. & $\begin{array}{l}\text { Is it possible to take over the controller without the consent of } \\
\text { the owner? }\end{array}$ & & $\mathrm{X}$ \\
\hline \multicolumn{4}{|c|}{$\ldots$} \\
\hline \multicolumn{4}{|c|}{5 group of questions - procedures } \\
\hline S. 1. & Is it possible that the flight takes place in the CTR? & $\mathrm{X}$ & \\
\hline S. 5. & $\begin{array}{l}\text { Is it possible that the BSP flight takes place in airspace structures } \\
\text { marked as military? }\end{array}$ & & $\mathrm{X}$ \\
\hline S. 15. & Is it possible that the operator will not be familiar with the AIP? & $\mathrm{X}$ & \\
\hline
\end{tabular}

The most questions is about occurrence hazard sources concern on RAPS operator (human). The positive answers can receive at questions about psychophysical operator state, as also his qualification and skills. After answering the questions from the checklist, the sources of threats are identified (tab. 2). The diagnosis is based on a checklist and answers to questions. The source of danger is recognized when the answer to the question coincides with the gray field in the table.

Table 2

\section{Fragments of recognized hazard sources}

\begin{tabular}{|l|l|}
\hline Mark & \multicolumn{1}{|c|}{ Sources of threats identified on the basis of selected control questions } \\
\hline 1 group of questions - environment conditions \\
\hline E. 1. & Occurrence of high point infrastructure facilities near the place of flights \\
\hline E. 2. & Unnoticed by the operator of linear infrastructure elements \\
\hline E. 4. & The occurrence of sudden, strong gusts of wind \\
\hline E. 6. & Close to the location of a high-traffic airport \\
\hline \multicolumn{2}{|l}{} \\
\hline$\ldots$ & \\
\hline 2 group of questions - regarding BSP \\
\hline H. 9. & Defects occurring on the surfaces of propellers \\
\hline$\ldots$ \\
\hline 3 group of questions - BSP operator \\
\hline LA. 2. & Bad mood of the BSP operator \\
\hline LA. 5. & Lack of knowledge of the airspace structure by the operator \\
\hline
\end{tabular}


table 2 cont.

\begin{tabular}{|l|l|}
\hline LA. 6. & Lack of knowledge of the BSP instruction manual \\
\hline LA. 14. & No compass calibration \\
\hline LA. 19. & An unconscious change in the mode in which BSP years \\
\hline$\ldots$ \\
\hline 4 group of questions - other related to man \\
\hline L. 3. & Taking over the controller without the owner's consent \\
\hline$\ldots$ \\
\hline 5 group of questions - procedures \\
\hline S. 1. & Conducting a flight in the CTR zone \\
\hline S. 15. & The operator does not recognize the AIP \\
\hline
\end{tabular}

After recognizing and formulating the sources of hazards, they are grouped to identify potential threats. These hazards are the result of the coexistence of sources of hazards in the area of analyzes $[4,5]$.

\section{Table 3}

\section{List of formulated hazards}

\begin{tabular}{|l|l|}
\hline Number of sources & Hazard \\
\hline $\begin{array}{l}\text { E. 1; E. 3; E.4; S. 13; } \\
\text { S. 17; H. 9; LA. 7; LB. 5; }\end{array}$ & $\begin{array}{l}\text { The possibility of BSP collision with a point infrastructure } \\
\text { facility. }\end{array}$ \\
\hline $\begin{array}{l}\text { E. } 2 ; \text { E. 3; S. 13; E. 7; H. 9; LA. 16; } \\
\text { LA. 19; LB. 5; }\end{array}$ & $\begin{array}{l}\text { The possibility of BSP collision with a linear } \\
\text { infrastructure object }\end{array}$ \\
\hline E. 5; E. 6; & The possibility of colliding UAV with other airship \\
\hline E. 3; H. 1; H. 2; E. 9; LA. 19; LB. 5; & The possibility of BSP collision with the ground \\
\hline E. 4; S. 16; LA. 6; LA. 8; LA. 9; & The possibility of BSP collision with a human being \\
\hline LB. 4; & The possibility of flight performed by an unauthorized person \\
\hline H. 6; & Possibility of detachment of SP elements in the air \\
\hline E. 5; LA. 1; & Possibility of collision in the air \\
\hline E. 8; & The BSP operator's vision can be overloaded \\
\hline LA. 2; LA. 10; & Possibility of occasional unavailability of the BSP operator \\
\hline LA. 2; LA. 10; & $\begin{array}{l}\text { The possibility of fainting the operator caused by its poor } \\
\text { condition }\end{array}$ \\
\hline H. 8; LA. 6; & Possibility of a BSP fire. \\
\hline LA. 18; LB. 1; LB. 3; LA. 4; & $\begin{array}{l}\text { The possibility of damage to someone else's property due } \\
\text { to operator error }\end{array}$ \\
\hline $\begin{array}{l}\text { LA. 21; S. 12; LB. 6; LA. 3; LA. 6, } \\
\text { S. 11; }\end{array}$ & Possibility of BSP damage during the start \\
\hline S. 4; S. 14; S. 15; \\
LA. 5; LA. 14, LA. 13; LB. 3;
\end{tabular}




\subsection{Risk estimation}

The method selected for risk estimation is MICE-RISK. This method belongs to the qualitative and determines the probability of the probability of the effects of the event. For risk estimation, the following relationship is used [4]:

$$
\mathrm{R}=3 \cdot \mathrm{K}_{1}+2 \cdot \mathrm{K}_{2}+2 \cdot \mathrm{K}_{3}
$$

where:

$\mathrm{K}_{1}$ - probability of catastrophe occurrence,

$\mathrm{K}_{2}$ - level of loss amounts expressed in PLN,

$\mathrm{K}_{3}$ - level of loss amount expressed in the number of victims.

The values of individual parameters are determined on the basis of assigned scales (tables 4-6).

Table 4

The quantification of levels $K_{1}$ - probability of occurrence of an event [4]

\begin{tabular}{|l|l|l|}
\hline Probability level $\mathbf{K}_{\mathbf{1}}$ & Characteristic & Chance of occurance \\
\hline 10 & very probable & $80 \%$ \\
\hline 6 & probable & $40 \%$ \\
\hline 3 & unlikley & $5 \%$ \\
\hline 1 & sporadically possible & $1 \%$ \\
\hline 0.1 & theoretically possible & $10^{-2} \%$ \\
\hline
\end{tabular}

Table 5

Scheme of quantification of $K_{2}$ levels - loss amounts expressed in PLN [4]

\begin{tabular}{|l|l|l|}
\hline K$_{2}$ level & Characteristic & Material losses \\
\hline 20 & serious catastrophe & $>3$ M PLN \\
\hline 10 & catastrophe & $0.3-30$ M PLN \\
\hline 5 & extra large & $30-300 \mathrm{~K}$ PLN \\
\hline 1 & large & $3-30 \mathrm{~K}$ PLN \\
\hline 0.1 & small & $<3 \mathrm{~K}$ PLN \\
\hline
\end{tabular}

Table 6

Scheme of quantification of levels $K_{3}$ - expressed in the number of victims [4]

\begin{tabular}{|l|l|l|}
\hline $\mathbf{K}_{\mathbf{2}}$ level & Characteristic & Human losses \\
\hline 20 & serious catastrophe & many mortal victims \\
\hline 10 & catastrophe & one mortal victim \\
\hline 5 & extra large & serious injury \\
\hline 1 & large & first aid \\
\hline 0.1 & small & nought human losses \\
\hline
\end{tabular}


After determining individual parameters and the risk indicator $\mathrm{R}$, the risk is assessed according to the five-degree scale adopted in the method (tab. 8) [4].

Table 7

The quantification of risk levels $R$ [4]

\begin{tabular}{|l|l|l|}
\hline Risk value (R) & Risk level & Risk category \\
\hline $\mathrm{R} \leq 10$ & negligible & \multirow{2}{*}{ Acceptable } \\
\hline $10<\mathrm{R} \leq 25$ & low & Tolerant \\
\hline $25<\mathrm{R} \leq 60$ & important & \multirow{2}{*}{ Unacceptable } \\
\hline $60<\mathrm{R} \leq 85$ & high & \\
\hline $\mathrm{R}>85$ & Very high & \\
\hline
\end{tabular}

Based on described method carried out risk estimation (tab. 8):

Table 8

Risk estimation

\begin{tabular}{|l|l|l|l|l|l|l|}
\hline $\begin{array}{c}\text { Number } \\
\text { of hazard }\end{array}$ & $\begin{array}{c}\text { Variable } \\
\mathbf{K}_{\mathbf{1}}\end{array}$ & $\begin{array}{c}\text { Variable } \\
\mathbf{K}_{\mathbf{2}}\end{array}$ & $\begin{array}{c}\text { Variable } \\
\mathbf{K}_{\mathbf{3}}\end{array}$ & $\begin{array}{c}\text { Risk } \\
\text { value (R) }\end{array}$ & Risk level & $\begin{array}{c}\text { Risk } \\
\text { category }\end{array}$ \\
\hline 1 & 3 & 0.1 & 0.1 & 9.4 & negligible & acceptable \\
\hline 2 & 6 & 0.1 & 1 & 18.4 & low & acceptable \\
\hline 3 & 0.1 & 10 & 1 & 22.3 & low & acceptable \\
\hline 4 & 6 & 0.1 & 1 & 20.2 & low & acceptable \\
\hline 5 & 3 & 1 & 10 & 31 & important & tolerablee \\
\hline 6 & 6 & 0.1 & 0.1 & 18.4 & low & acceptable \\
\hline 7 & 1 & 0.1 & 0.1 & 3.4 & negligible & acceptable \\
\hline 8 & 6 & 5 & 5 & 38 & important & tolerable \\
\hline 9 & 0.1 & 0.1 & 0.1 & 0.7 & low & acceptable \\
\hline 10 & 0.1 & 0.1 & 0.1 & 0.7 & low & acceptable \\
\hline 11 & 0.1 & 0.1 & 0.1 & 0.7 & low & acceptable \\
\hline 12 & 1 & 0.1 & 0.1 & 3.4 & negligible & acceptable \\
\hline 13 & 3 & 1 & 0.1 & 11.2 & low & acceptable \\
\hline 14 & 3 & 0.1 & 0.1 & 9.4 & negligible & acceptable \\
\hline 15 & 6 & 1 & 0.1 & 20.2 & low & acceptable \\
\hline 16 & 6 & 5 & 0.1 & 28.2 & important & tolerable \\
\hline 17 & 0.1 & 0.1 & 1 & 2.5 & negligible & acceptable \\
\hline 18 & 3 & 0.1 & 0.1 & 9.4 & negligible & acceptable \\
\hline
\end{tabular}

Among the defined hazards, three have reached the level of risk identified as important, eight as negligible and seven as low. After the risk categorization, the results were: 3 hazards fall into the tolerated category, while fifteen hazards fall into an acceptable category. The rare of the identified hazards did not reach the unacceptable level. In the case of such a level, the analyzed system should not be allowed to function. The estimated risk values are small due to the amount of losses 
expressed in zlotys, which in the case of unmanned aircraft will not be high. Three of the formulated hazards have achieved the tolerable risk category. When identifying this category, preventive actions should be taken, which will lead to the removal of sources of danger or to reduce the risk. However, the level of risk should be constantly monitored. Fifteen hazards have reached the level of accreditation. This means that there is no need to take risk-reducing measures, but you should still control its level [4].

\section{Conclusions}

Recreational flights with unmanned aerial vehicles often take place in the airspace above the urban area. For this reason, many risks are generated related to the environment, the structure of the airspace, legal restrictions, population density, as well as the operator's person and the operated unmanned aerial vehicle. Due to the lack of enforcement of existing regulations and the ease of access to BSP, this area is particularly vulnerable to the occurrence of hazards. In the analyzed area of analysis, a list of 72 questions about the source of the threat was prepared, of which 45 sources of threats were identified. Based on them, 18 hazards were identified. In further work a risk management model should be developed. Determine how to respond to threats that lead to an improvement in the level of risk The developed methods should be reported to the relevant state authorities, e.g. to the Civil Aviation Authority for the purpose of their widest possible promotion. Due to the growing interest in non-commercial use of BSP in both VLOS and BVLOS flights, it is appropriate to extend the analysis to other purposes and areas of unmanned operations. Guided by the ideas and good practices of manned aviation, it is necessary to harmonize legal regulations concerning safety management in unmanned flights.

\section{References}

1. Chruzik K., Fellner A., Risk managemant in transport. Logistyka, No. 4, 2015.

2. Cieślak E., Safety in aviation. Safety and reliability in aviation, Toruń 2009.

3. Fellner A., Osowski M.: Taking into account the human factor in the analysis of the safety of the human resources management process. Forensics problems, Vol. 290(4), 2015.

4. Galant M.: Limiting the risk of threats in general aviation through the use of a system monitoring the psychophysical state of the pilot. PhD dissertation, Poznań 2017.

5. Gill A.: The concept of a security system for selected hazards in tram communication. Technic of Rail Transport, No. 10, 2013. 
6. Grochowski M.: Conclusions from the investigation of aviation events conducted by the State Aviation Aerodrome Accident Investigation Commission. Safety and reliability in aviation, Toruń 2009.

7. International Civil Aviation Organization, Safety Management, Pub. International Civil Aviation, Warszawa 2009.

8. International Civil Aviation Organization, Safety Management Manual, Doc. 9859 ICAO, Wyd. Urząd Lotnictwa Cywilnego, Warszawa 2013.

9. Kadziński A.: A study of selected aspects of reliability of railway vehicle systems and objects. Publishing of Poznan University of Technology, Poznań 2013.

10. Klich E.: Safety of flight operations. Radom 2011.

11. Koradecka D.: Safety and ergonomics of work. Vol. 2, Publishing CIOP, Warszawa 1999.

12. Krystek R. (ed.): Zintegrowany System Bezpieczeństwa Transportu. Tom III. Koncepcja zintegrowanego systemu bezpieczeństwa transportu w Polsce. [Integrated Transport Safety System. Volume III. The concept of an integrated transport security system in Poland]. Politechnika Gdańska, WKŁ, Warszawa 2010.

13. Makarowski R., Smolicz T.: Human factor in aviation accidents Pub. Adriana Aviation sp. z o.o., Kosowizna 2012.

14. Merkisz J., Galant M., Karpiński D.: Assessment and assessment of risk during the flight of the glider in the traffic circuit. Logistics, nr 4, 2014.

15. Merkisz J., Galant M.: Risk management of hazards for route between ŁawicaKobylnica-Bednary airports, Journal of KONBiN, No. 2(22) 2012.

16. Polska Agencja Żeglugi Powietrznej, AIP Polska, Warszawa 2017.

17. Romanowska-Słomka I., Słomka A.: Professional risk management. Publishing Tarbonus, Tarnobrzeg 2005.

18. Tkacz M.: Drones - legal aspect and legal consequences from the point of view of the police. Materiały konferencyjne, Konferencja Bezpieczeństwa w Lotnictwie Cywilnym, Warszawa 2018.

19. Urząd Lotnictwa Cywilnego, Krajowy Plan Bezpieczeństwa 2017-2020, Warszawa 2017.

20. www.pansa.pl 


\section{ANALIZA RYZYKA ZAGROŻEŃ W LOCIE BEZZAŁOGOWYM STATKIEM POWIETRZNYM}

\section{Wprowadzenie}

Lotnictwo jest najlepiej zorganizowaną gałęzią transportu. Szereg procedur i badań prowadzonych $\mathrm{w}$ tej dziedzinie umożliwia podróżowanie w stosunkowo krótkim czasie do wszelkich zakątków świata. Wraz z rozwojem lotnictwa komercyjnego, obserwuje się również rosnącą popularność lotnictwa ogólnego, w tym bezzałogowych statków powietrznych (BSP), które wedhug ICAO (International Civil Aviation Organizaton) definiowane są, jako bezpilotowe pojazdy powietrzne, niezabierające na pokład człowieka, pilotowane zdalnie lub autonomicznie, wykonujące zadania w locie [18]. Wraz z rozwojem BSP zaistniała konieczność prowadzenia badań w celu zapewnienia akceptowalnego poziomu ryzyka. Obecnie obserwuje się trend mający na celu ograniczenie błędów ludzkich. W celu zapewnienia bezpieczeństwa w lotnictwie ważne jest utrzymywanie ryzyka na odpowiednim poziomie. W odpowiedzi na to powstają coraz nowsze i dokładniejsze standardy i systemy bezpieczeństwa. Zgodnie $\mathrm{z}$ wymaganiami ICAO rozróżnia się trzy strategie zarządzania bezpieczeństwem: metodę reaktywną, prewencyjną i prognozującą [8]. Pierwsza z nich odpowiada za wydarzenia, które już miały miejsce, takie jak incydenty i wypadki. Metoda prewencyjna aktywnie rozpoznaje ryzyko poprzez analizę czynności organizacyjnych. Ostatnią z metod jest metoda prognozująca, która ocenia działanie systemu w czasie rzeczywistym podczas zwykłych operacji w celu określania potencjalnych zagrożeń [14]. W niniejszym artykule skupino się na formułowaniu zagrożeń w wybranym obszarze analiz, co jest jednym $\mathrm{z}$ istotnych etapów procesu oceny ryzyka. W załogowym transporcie lotniczym przez lata powstało wiele norm i przepisów prawnych $[8,19]$. Dla wciąż rozwijających się BSP nie stworzono jeszcze żadnych oficjalnych zasad pochodzących od ICAO. Jedyną dostępną formę przepisów dla obszaru BSP opisuje JARUS (Joint Authorities for Rulemaking on Unmanned Systems), jednak zawarte tam informacje nie mają mocy prawnej, a jedynie charakter doradczy. Niniejszy artykuł jest próbą adaptacji dostępnych i powszechnie wykorzystywanych metod zarządzania ryzykiem zagrożeń do obszaru BSP. 


\section{Algorytm zarządzania ryzykiem}

Ryzyko definiuje się jako kombinację prawdopodobieństwa aktywizacji zagrożenia $\mathrm{w}$ zdarzeniu niepożądanym i spowodowanych $\mathrm{w}$ związku z tym szkód [1]. W celu osiągnięcia jego akceptowalnego poziomu należy zastosować algorytm zarządzania ryzykiem (rys. 1). Algorytm jest podzielony na dwie główne części: ocenę ryzyka i reagowanie na ryzyko. Na pierwszą część składa się analiza i wartościowanie ryzyka. W celu dokonania analizy należy rozpoznać obszar analiz, źródła zagrożeń i sformułować zagrożenia.

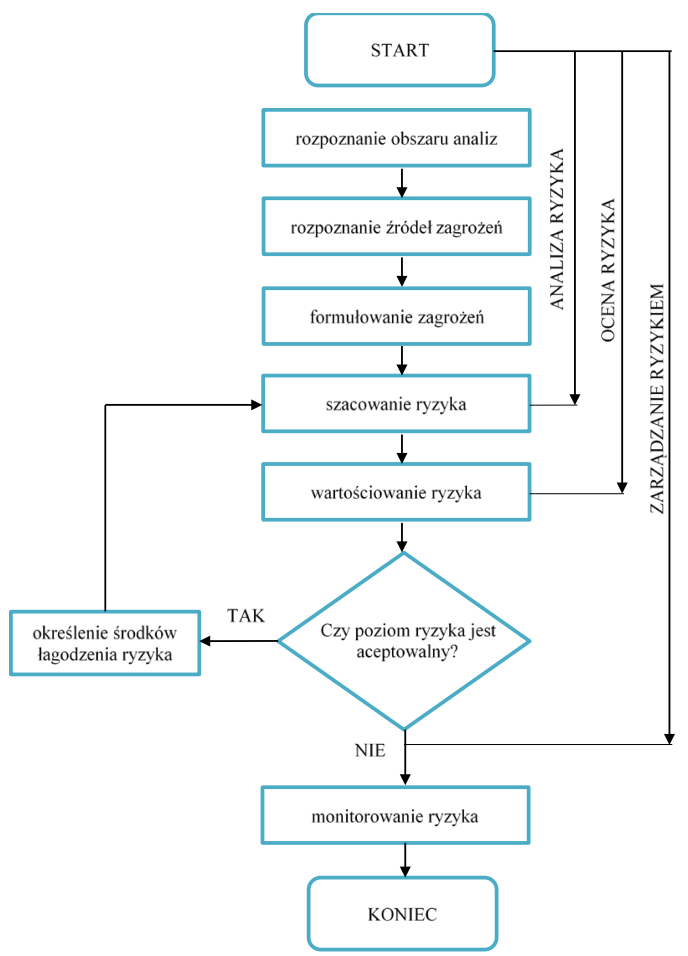

Rys. 1. Algorytm zarządzania ryzykiem opracowanie własne na podstawie $[4,9,11,12,17]$

Pierwszym krokiem w algorytmie zarządzania ryzykiem jest rozpoznanie obszaru analiz, rozumiane, jako jego identyfikacja lub opis. Rozpoznanie obszaru analiz jest równoznaczne ze zbieraniem informacji niezbędnych do przeprowadzenia oceny ryzyka zagrożeń, uwzględniając wszystkie czynniki otoczenia mogące mieć wpływ na generowanie źródeł zagrożeń. Po rozpoznaniu obszaru analiz przystępuje się do identyfikacji źródeł zagrożeń. Można ją przeprowadzić za pomocą ułożenia listy pytań kontrolnych. Pytania kontrolne opracowuje się na 
podstawie analizy zebranych informacji, której wynikiem powinno być ustalenie, czy w analizowanym obszarze występują czynniki, które mogą być uznane za źródła zagrożeń. Po rozpoznaniu obszaru analiz następuje proces identyfikacji źródeł zagrożeń, który jest jednym $\mathrm{z}$ najważniejszych kroków w procesie zarządzania ryzykiem.

Zgodnie z SMM (Safety Management Manual), jest to sformalizowane, udokumentowane działanie opierające się na reaktywnych, proaktywnych i prognostycznych metodach gromadzenia danych dotyczących bezpieczeństwa [4, 7]. Najbardziej pożądana jest metodyka przewidywalna, zwana również podejściem predykcyjnym (ang. predictive), obejmująca działania związane z przewidywaniem przyszłych zdarzeń i trendów. Na podstawie bieżących i historycznych wydarzeń poszukiwane są zależności pozwalające na prognozowanie przyszłych źródeł zagrożeń. Opracowano wiele modeli dotyczących teorii bezpieczeństwa lotów, m.in. [10]: teoria Singletona, teoria C.O. Millera, teoria 5M, model SHEL(L), teoria B.F. Łomowa i K.K. Płatnowa, teoria Jemesa Reasona, HFACS System analizy i klasyfikacji wpływu czynnika ludzkiego. Bez względu na różnorodność wymienionych teorii, niezmiennie czynnik ludzki jest kluczowym elementem, bez którego system nie może działać ani powstać. Na przykład w modelu SHEL ( $\mathrm{S}$ - software, $\mathrm{H}$ - hardware, E - environment, L - liveware) Hawkinsa z 1975 r. człowiek przedstawiony jest jako krytyczny element systemu człowiek - człowiek, człowiek - środowisko, człowiek - technika, człowiek automatyka, ale też jako najbardziej elastyczny, potrafiący ingerować w każdy z pozostałych elementów systemu. To od niego w dużym stopniu zależy, czy operacja lotnicza zakończy się sukcesem. Model SHELL jest narzędziem koncepcyjnym wykorzystywanym do analizowania wzajemnego oddziaływania różnorodnych komponentów systemu. Schemat ideowy modelu SHELL przedstawiony został na rys. 3. Model ten kładzie nacisk na indywidualne i ludzkie punkty styku z innymi składnikami i cechami systemu. Czynnik ludzki (L) zajmuje centralną pozycję w modelu. Poza tym, że występują powiązania z każdym innym czynnikiem (S, H, E), dodany jest jeszcze dodatkowy element L mówiący o tym, że zakłócenia występują również na styku czynnik ludzki czynnik ludzki, a dopasowanie czynnika do pozostałych elementów powinno stanowić o sprawnej pracy systemu jako całości $[3,4,6,13]$. W związku ze złożonością procesu zarządzania ryzykiem, $w$ niniejszym artykule skupiono się na działaniach związanych $\mathrm{z}$ analizą ryzyka, a dokładniej, skorzystano z trzech pierwszych etapów algorytmu zarządzania ryzykiem. W przyszłości będzie to podstawą do dalszych rozważań nad oceną ryzyka. 


\section{Realizacja wybranych kroków algorytmu zarządzania ryzykiem}

\subsection{Rozpoznaie obszaru analiz}

Identyfikacja obszaru analiz jest kluczowym etapem algorytmu zarządzania ryzykiem. Określenie go powinno być przeprowadzone na tyle ogólnie, aby możliwa była pewna uniwersalność, a zarazem na tyle szczegółowo, aby uniknąć błędów w interpretacji wyników. Jako obszar analiz przyjęto lot bezzałogowego statku powietrznego z widocznością (VLOS Visual Line Of Sight) w przestrzeni niekontrolowanej FIR (Flight Information Region) Warszawa nad terenem zielonym, na przedmieściach średniej wielkości miasta, w tym przypadku Poznania (rys. 2). W odległości kilkuset metrów przebiega granica CTR (z ang. Control Zone - strefa kontrolowana lotnisk). Nad obszarem rozciąga się TMA (z ang. Terminal Manoeuvring Area - rejon kontrolowany lotniska). W promieniu kilku kilometrów znajdują się tory kolejowe, droga szybkiego ruchu, oraz port lotniczy.

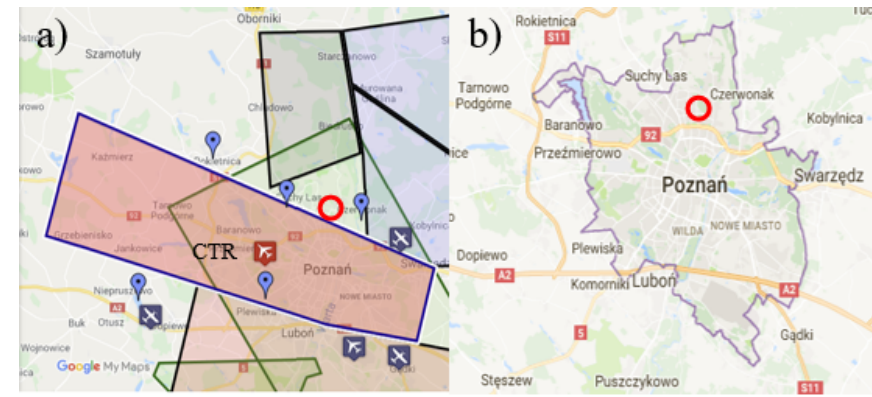

Rys. 2. Przedstawienie obszaru analiz (czerwonym okręgiem oznaczono granice obszaru):

a) mapa $z$ podziałem na strefy przestrzeni powietrznej występujące w pobliżu,

b) umiejscowienie obszaru na mapie Poznania

Bezzałogowym statkiem powietrznym wybranym do wykonania operacji lotniczej, na podstawie której przeprowadzona zostanie analiza ryzyka zagrożeń, jest quadrokopter (bezzałogowy statek powietrzny posiadający cztery bezszczotkowe silniki elektryczne) o masie ok. 1,2 kg i przewidywanym czasie lotu ok. 20 min. Posiada on funkcję powrotu do domu (Return to Home - RTH). Jego zasięg to ok. $100 \mathrm{~m}$, maksymalna wysokość lotu to $5000 \mathrm{~m}$ n.p.m., a prędkość lotu $10 \mathrm{~m} / \mathrm{s}$. Wyposażony jest GPS oraz akcelerometr. Zakłada się, że BSP nie jest wyposażony w wystarczającą liczbę czujników, aby zastosować funkcję pozwalającą na omijanie przeszkód terenowych. Nie posiada opcji auto-hover pozwalającej na stabilne zawiśnięcie w jednej pozycji w przypadku puszczenia drążków 
sterujących, nie ma też funkcji automatycznego startu oraz nie ma możliwości ustawienia granic bezpiecznego latania. Ze względu na to, że BSP nie może omijać przeszkód w funkcji powrotu do domu, należy ustawić odpowiedni pułap lotu (dostosowany do wysokości przeszkód terenowych znajdujących się w zasięgu BSP). Funkcja RTH nie zadziała, jeśli sygnał GPS jest za słaby. W wybranym BSP dostępne są trzy tryby lotu: tryb P (positioning) - sygnał na podstawie GPS (PGPS, P-ATTI), A (altittude) - pozycjonowanie na podstawie danych z barometru i F (function) - inteligentna orientacja BSP. Tryby zmienia się za pomocą przełącznika w kontrolerze. Kontroler pozwala na przesyłanie sygnału na odległość $1 \mathrm{~km}$. Najlepiej, gdy anteny kontrolera są zgięte pod kątem $45^{\circ}$. BSP zasila bateria litowo-polimerowa o pojemności $4200 \mathrm{mAh}$. Nie zaleca się używania akumulatora w niskich temperaturach, poniżej $10^{\circ} \mathrm{C}$. Temperatura samego akumulatora powinna przekraczać $5^{\circ} \mathrm{C}$. Rolę operatora w obszarze analiz pełni człowiek (mężczyzna), nieposiadający świadectwa kwalifikacji, mający powyżej 18 roku życia, któremu towarzyszy dziecko. Celem lotu jest wykonanie zdjęć widokowych przeznaczonych do użytku prywatnego oraz zapoznanie dziecka z nowymi technologiami.

\subsection{Proces identyfikacji źródeł zagrożeń oraz formułowania zagrożeń}

W celu rozpoznania źródeł zagrożeń należy połączyć podejście proaktywne, reaktywne i prognozujące. Na bazie wszystkich trzech metodologii wyodrębniono źródła danych mogące być przydatne w procesie identyfikacji źródeł zagrożeń. Najczęściej stosowaną metodą pozwalającą na określenie możliwych źródeł zagrożeń jest procedura listy kontrolnej [4]. Metoda ta jest jedną z najbardziej sformalizowanych, a zarazem rzetelnych procedur. Jej sporządzenie poprzedza się inną procedurą, tzw. burzą mózgów, która pozwala na wyłonienie szczególnie istotnych źródeł zagrożeń. Przy tworzeniu list kontrolnych uwzględnia się informacje o źródłach zagrożeń w danym obszarze oraz o ich typie. Do wykonania listy kontrolnej pytań o występowanie źródeł zagrożeń obszar analizy podzielono na pięć grup, zgodnie z modelem SHELL (rys. 3) opisanym w punkcie 2: S - źródła zagrożeń dotyczące procedur, $\mathrm{H}$ - źródła zagrożeń dotyczące BSP, E - źródła zagrożeń związane $\mathrm{z}$ warunkami środowiskowymi, $\mathrm{L}_{\mathrm{A}}$ - operator BSP człowiek, $\mathrm{L}_{\mathrm{B}}-$ inne.

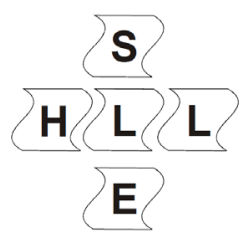

Rys. 3. Schemat ideowy SHELL $[2,4,6]$ 
Do stworzenia listy pytań kontrolnych o występowanie źródeł zagrożeń w analizowanym obszarze (tab. 1) wykorzystano m.in. plan użytkowania przestrzeni powietrznej (Airspace Use Plan) [20], zbiór informacji lotniczych (Aeronautical Information Publication) [16] oraz instrukcje użytkowania wybranych BSP. Kolejnym krokiem po opracowaniu listy pytań kontrolnych jest udzielenie odpowiedzi na znajdujące się w niej pytania (tab. 1) przez umieszczenie znacznika odpowiedzi w odpowiedniej kolumnie („tak” lub „nie”) [4, 7]. Wśród pól wyboru znajdują się tzw. pola krytyczne oznaczone przez zacieniowanie komórki. Jeżeli znak odpowiedzi umieszczony zostanie w polu krytycznym, to sugeruje to występowanie źródła zagrożeń. Kolejno następuje rozpoznanie źródeł zagrożeń na podstawie wydzielenia z listy tych pytań, w których odpowiedź znalazła się w polu krytycznym.

Tabela 1

Fragmenty listy kontrolnej pytań o występowanie źródeł zagrożeń w analizowanym locie wraz z udzielonymi odpowiedziami

\begin{tabular}{|c|c|c|c|}
\hline Ozn. & Pytanie & TAK & NIE \\
\hline \multicolumn{4}{|c|}{1 grupa pytań - warunki środowiskowe } \\
\hline E. 1. & $\begin{array}{l}\text { Czy istnieje możliwość, że w pobliżu miejsca wykonywania } \\
\text { lotów znajdują się wysokie obiekty infrastruktury punktowej? }\end{array}$ & $\mathrm{X}$ & \\
\hline E. 2. & $\begin{array}{l}\text { Czy istnieje możliwość, że operator nie zauważy elementów } \\
\text { infrastruktury liniowej? }\end{array}$ & $\mathrm{X}$ & \\
\hline E. 4. & $\begin{array}{l}\text { Czy istnieje możliwość występowania nagłych silnych } \\
\text { powiewów wiatru? }\end{array}$ & $\mathrm{X}$ & \\
\hline E. 6. & $\begin{array}{l}\text { Czy istnieje możliwość, że w bezpośrednim otoczeniu znajduje } \\
\text { się lotnisko o dużym natężeniu ruchu? }\end{array}$ & $\mathrm{X}$ & \\
\hline E. 10. & Czy istnieje możliwość, że lot jest wykonywany nocą? & & $\mathrm{X}$ \\
\hline E. 14. & Czy istnieje możliwość wystąpienia ujemnych temperatur? & & $\mathrm{X}$ \\
\hline \multirow{2}{*}{\multicolumn{4}{|c|}{$\begin{array}{l}\ldots \\
2 \text { grupa pytań }- \text { dotyczace BSP }\end{array}$}} \\
\hline & \multicolumn{3}{|c|}{2 grupa pytań - dotyczące BSP } \\
\hline H. 5. & Czy istnieje pewność, że kontroler jest naładowany? & $\mathrm{X}$ & \\
\hline H. 9. & $\begin{array}{l}\text { Czy istnieje możliwość, że występują ubytki na powierzchni } \\
\text { śmigła? }\end{array}$ & $\mathrm{X}$ & \\
\hline \multicolumn{4}{|c|}{$\ldots$} \\
\hline \multicolumn{4}{|c|}{3 grupa pytań - operator BSP } \\
\hline LA. 2. & Czy istnieje możliwość, że operator BSP się źle czuje? & $\mathrm{X}$ & \\
\hline $\mathrm{L}_{\mathrm{A}} .5$. & $\begin{array}{l}\text { Czy istnieje możliwość, że operator nie zna struktury przestrzeni } \\
\text { powietrznej? }\end{array}$ & $\mathrm{X}$ & \\
\hline $\mathrm{L}_{\mathrm{A}} .6$. & $\begin{array}{l}\text { Czy istnieje możliwość, że operator nie zapoznał się z instrukcją } \\
\text { obsługi? }\end{array}$ & $\mathrm{X}$ & \\
\hline LA. 14. & Czy istnieje możliwość, że operator nie skalibrował GPS? & $\mathrm{X}$ & \\
\hline
\end{tabular}


cd. tabeli 1

\begin{tabular}{|c|c|c|c|}
\hline LA. 19. & $\begin{array}{l}\text { Czy istnieje możliwość, że operator zignoruje ostrzeżenie o } \\
\text { niskim poziomie naładowania baterii? }\end{array}$ & $\mathrm{X}$ & \\
\hline $\mathrm{L}_{\mathrm{A}} \cdot 22$. & $\begin{array}{l}\text { Czy istnieje pewność, że operator najpierw włączy nadajnik, a } \\
\text { później BSP? }\end{array}$ & & $\mathrm{X}$ \\
\hline \multicolumn{4}{|c|}{ 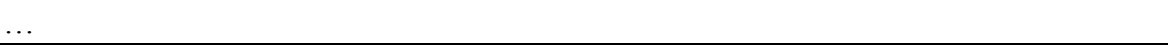 } \\
\hline \multicolumn{4}{|c|}{4 grupa pytań - inne związane z człowiekiem } \\
\hline Lв. 3. & $\begin{array}{l}\text { Czy istnieje możliwość, przejęcia kontrolera bez zgody } \\
\text { właściciela? }\end{array}$ & & $\mathrm{X}$ \\
\hline \multirow{2}{*}{\multicolumn{4}{|c|}{5 grupa pytan - procedury }} \\
\hline & & & \\
\hline S. 1. & Czy istnieje możliwość, że lot odbywa się w CTR? & $X$ & \\
\hline S. 5. & $\begin{array}{l}\text { Czy istnieje możliwość, że lot BSP odbywa się w strukturach } \\
\text { przestrzeni powietrznej oznaczonych jako militarne? }\end{array}$ & & $\mathrm{X}$ \\
\hline S. 15. & Czy istnieje możliwość, że operator nie zapozna się z AIP? & $\mathrm{X}$ & \\
\hline
\end{tabular}

Najwięcej pytań o występowanie źródeł zagrożeń dotyczy operatora BSP człowieka. Odpowiedzi pozytywne można uzyskać zarówno w pytaniach o stan psychofizyczny operatora, jak i o jego kwalifikacje i umiejętności. Po udzieleniu odpowiedzi na pytania z listy kontrolnej następuje rozpoznanie źródeł zagrożeń na podstawie listy kontrolnej i odpowiedzi na pytania (tab. 2). Źródło zagrożenia zostaje rozpoznane, kiedy odpowiedź na pytanie pokrywa się z szarym polem w tabeli.

\section{Tabela 2}

\section{Rozpoznane źródła zagrożeń}

\begin{tabular}{|l|l|}
\hline \multicolumn{1}{|c|}{ Ozn. } & \multicolumn{1}{c|}{ Źródla zagrożeń rozpoznane na podstawie wybranych pytań kontrolnych } \\
\hline E.1. & $\begin{array}{l}\text { Występowanie wysokich obiektów infrastruktury punktowej w pobliżu miejsca } \\
\text { wykonywania lotów }\end{array}$ \\
\hline E. 2. & Niezauważenie przez operatora elementów infrastruktury liniowej \\
\hline E. 4. & Wystąpienie nagłych, silnych powiewów wiatru \\
\hline E. 6. & Bliska lokalizacja lotniska o dużym natężeniu ruchu \\
\hline$\ldots$ \\
\hline 2 grupa źródeł zagrożeń - dotyczące BSP \\
\hline H. 9. & Występowanie ubytków na powierzchniach śmigieł \\
\hline$\ldots$ \\
\hline 3 grupa źródeł zagrożeń - operator BSP \\
\hline LA. 2. & Złe samopoczucie operatora BSP \\
\hline LA. 5. & Brak znajomości struktury przestrzeni powietrznej przez operatora \\
\hline LA. 6. & Brak znajomości instrukcji obsługi BSP \\
\hline LA. 14. & Brak kalibracji kompasu \\
\hline
\end{tabular}


cd. tabeli 2

\begin{tabular}{|l|l|}
\hline LA. 19. & Nieświadoma zmiana trybu, w którym lata BSP \\
\hline$\ldots$ \\
\hline 4 grupa źródeł zarożeń - inne związane z człowiekiem \\
\hline LB. 3. & Przejęcie kontrolera bez zgody właściciela \\
\hline$\ldots$ \\
\hline 5 grupa źródeł zagrożeń - procedury \\
\hline S. 1. & Przeprowadzenie lotu w strefie CTR \\
\hline S. 15. & Niezapoznanie się operatora z AIP \\
\hline
\end{tabular}

Po rozpoznaniu i sformułowaniu źródeł zagrożeń następuje ich grupowanie mające na celu określenie potencjalnych zagrożeń (tab. 3). Zagrożenia te są wynikiem współistnienia źródeł zagrożeń w obszarze analiz [4, 5]. W analizie ryzyka zidentyfikowano 18 zagrożeń, dla których następnie przeprowadzone zostanie szacowanie ryzyka wybraną metodą.

\section{Tabela 3}

\section{Zagrożenia}

\begin{tabular}{|l|l|}
\hline \multicolumn{1}{|c|}{ Nr źródla } & \multicolumn{1}{c|}{ Zagrożenie } \\
\hline $\begin{array}{l}\text { E. 1; E.3; E.4; S. 13; } \\
\text { S. 17; H. 9; LA. 7; LB. 5; }\end{array}$ & $\begin{array}{l}\text { Możliwość zderzenia BSP z obiektem infrastruktury } \\
\text { punktowej }\end{array}$ \\
\hline $\begin{array}{l}\text { E. 2; E.3; } \\
\text { S. 13; E. 7; H. 9; } \\
\text { LA. 16; LA. 19; LB. 5; }\end{array}$ & Możliwość zderzenia BSP z obiektem infrastruktury liniowej \\
\hline E. 5; E. 6; & $\begin{array}{l}\text { Możliwość zderzenia BSP z załogowym statkiem } \\
\text { powietrznym }\end{array}$ \\
\hline $\begin{array}{l}\text { E. 3; H. 1; } \\
\text { H. 2; E. 9; LA. 19; LB. 5; }\end{array}$ & Możliwość zderzenia BSP z ziemią \\
\hline $\begin{array}{l}\text { E. 4; S. 16; LA. 6; } \\
\text { LA. 8; LA. 9; }\end{array}$ & Możliwość zderzenia BSP z człowiekiem \\
\hline LB. 4; & Możliwość lotu wykonywanego przez osobę nieupoważnioną \\
\hline H. 6; & Możliwość oderwania się elementów SP w powietrzu \\
\hline E. 5; LA. 1; & Możliwość wystąpienia kolizji w powietrzu \\
\hline E. 8; & Możliwość przeciążenia narządu wzroku operatora BSP \\
\hline $\begin{array}{l}\text { LA. 2; } \\
\text { LA. 10; }\end{array}$ & $\begin{array}{l}\text { Możliwość wystąpienia chwilowej niedyspozycji operatora } \\
\text { BSP }\end{array}$ \\
\hline LA. 2; LA. 10; & $\begin{array}{l}\text { Możliwość zasłabnięcia operatora wywołanego jego złym } \\
\text { stanem }\end{array}$ \\
\hline H. 8; LA. 6; & Możliwość wystąpienia pożaru BSP. \\
\hline LA. 18; LB. 1; LB. 3; LA. 4; & $\begin{array}{l}\text { Możliwość uszkodzenia cudzego mienia wskutek błędu } \\
\text { operatora }\end{array}$ \\
\hline $\begin{array}{l}\text { LA. 21; S. 12; LB. 6; LA. 3; } \\
\text { LA. 6, S. 11; }\end{array}$ & Możliwość uszkodzenia BSP podczas startu \\
\hline
\end{tabular}


cd. tabeli 3

\begin{tabular}{|l|l|}
\hline $\begin{array}{l}\text { S. 4; S. 14; S. 15; } \\
\text { LA. 5; LA. 14, LA. 13; LB. 3; }\end{array}$ & $\begin{array}{l}\text { Możliwość naruszenia przestrzeni zarezerwowanej lub } \\
\text { wydzielonej }\end{array}$ \\
\hline $\begin{array}{l}\text { S. 1; S. 14; S. 15; LA. 5; LA. } \\
\text { 14, LA. 13; LB. 3; }\end{array}$ & Możliwość naruszenia przestrzeni kontrolowanej \\
\hline S. 16; LB. 1; & $\begin{array}{l}\text { Możliwość doznania uszczerbku na zdrowiu przez osoby } \\
\text { znajdujące się na ziemi }\end{array}$ \\
\hline S. 7. LA. 6; & Możliwość uszkodzenia BSP podczas lądowania \\
\hline
\end{tabular}

\subsection{Szacowanie ryzyka}

Metoda, którą wybrano do szacowania ryzyka, to MICE-RISK. Metoda ta należy do jakościowych i określa ryzyko prawdopodobieństwa skutków zdarzenia. Do szacowania ryzyka wykorzystuje się następującą zależność [4]:

$$
\mathrm{R}=3 \cdot \mathrm{K}_{1}+2 \cdot \mathrm{K}_{2}+2 \cdot \mathrm{K}_{3}
$$

gdzie:

$\mathrm{K}_{1}$ - prawdopodobieństwo wystąpienia zdarzenia wypadkowego,

$\mathrm{K}_{2}$ - poziom wielkości strat wyrażony w złotówkach,

$\mathrm{K}_{3}$ - poziom wielkości strat wyrażony w liczbie ofiar.

Wartości poszczególnych parametrów określa się na podstawie przypisanych skal (tabele 4-6).

Tabela 4

Schemat kwantyfikacji poziomów $K_{1}$ - prawdopod. wystąpienia zdarzenia [4]

\begin{tabular}{|c|c|c|}
\hline Poziom $\mathrm{K}_{1}$ & Charakterystyka & Szansa wystappienia \\
\hline 10 & bardzo prawdopodobne & $80 \%$ \\
\hline 6 & prawdopodobne & $40 \%$ \\
\hline 3 & mało prawdopodobne, ale możliwe & $5 \%$ \\
\hline 1 & sporadycznie możliwe & $1 \%$ \\
\hline 0,1 & teoretycznie możliwe & $10^{-2} \%$ \\
\hline
\end{tabular}

Tabela 5

Schemat kwantyfikacji poziomów $K_{2}$ - wyrażony w zlotówkach [4]

\begin{tabular}{|c|c|c|}
\hline Poziom $\mathrm{K}_{2}$ & Charakterystyka & Straty materialne \\
\hline 20 & poważny wypadek & $>3 \mathrm{mln} \mathrm{zl}$ \\
\hline 10 & wypadek & $0,3-3 \mathrm{mln} \mathrm{zl}$ \\
\hline 5 & poważny incydent & $30-300$ tys. $\mathrm{zl}$ \\
\hline 1 & incydent & $3-30$ tys. $\mathrm{zl}$ \\
\hline 0,1 & zdarzenie lotnicze & $<3$ tys. zł \\
\hline
\end{tabular}




\section{Tabela 6}

\section{Schemat kwantyfikacji poziomów K3 - wyrażony w liczbie ofiar [4]}

\begin{tabular}{|c|c|c|}
\hline Poziom $\mathrm{K}_{3}$ & Charakterystyka & Straty materialne \\
\hline 20 & poważny wypadek & więcej niż jedna ofiara śmiertelna \\
\hline 10 & wypadek & jedna ofiara śmiertelna \\
\hline 5 & poważny incydent & ciężkie uszkodzenia ciała \\
\hline 1 & incydent & udzielenie pierwszej pomocy \\
\hline 0,1 & zdarzenie lotnicze & brak strat w ludziach \\
\hline
\end{tabular}

Po określeniu poszczególnych parametrów oraz wskaźnika ryzyka $\mathrm{R}$, wartościowanie ryzyka odbywa się według przyjętej w metodzie pięciostopniowej skali (tab. 8) [4].

Tabela 7

Schemat kwantyfikacji poziomów ryzyka $R$ i jego kategorii [4]

\begin{tabular}{|l|l|l|}
\hline \multicolumn{1}{|c|}{ Wartość (R) } & \multicolumn{1}{|c|}{ Charakterystyka } & \multirow{2}{*}{ Kategoria ryzyka } \\
\hline $\mathrm{R} \leq 10$ & pomijalne & \multirow{2}{*}{ akceptowalne } \\
\hline $10<\mathrm{R} \leq 25$ & małe & tolerowane \\
\hline $25<\mathrm{R} \leq 60$ & istotne & \multirow{2}{*}{ nieakcpetowalne } \\
\hline $60<\mathrm{R} \leq 85$ & duże & \\
\hline $\mathrm{R}>85$ & bardzo duże & \\
\hline
\end{tabular}

Bazując na opisanej metodzie przeprowadzono szacowanie ryzyka (tab. 8).

Tabela 8

\section{Szacowanie ryzyka}

\begin{tabular}{|l|l|l|l|c|l|l|}
\hline $\begin{array}{c}\text { Nr } \\
\text { zagrożenia }\end{array}$ & $\mathbf{K}_{\mathbf{1}}$ & $\mathbf{K}_{\mathbf{2}}$ & \multicolumn{1}{|c|}{$\mathbf{K}_{\mathbf{3}}$} & $\begin{array}{c}\text { Wartość } \\
\text { wskaźnika ryzyka }\end{array}$ & $\begin{array}{c}\text { Poziom } \\
\text { ryzyka }\end{array}$ & Kategoria ryzyka \\
\hline 1 & 3 & 0,1 & 0,1 & 9,4 & pomijalne & akcpetowalne \\
\hline 2 & 6 & 0,1 & 1 & 18,4 & małe & akcpetowalne \\
\hline 3 & 0,1 & 10 & 1 & 22,3 & małe & akcpetowalne \\
\hline 4 & 6 & 0,1 & 1 & 20,2 & małe & akcpetowalne \\
\hline 5 & 3 & 1 & 10 & 31 & istotne & tolerowane \\
\hline 6 & 6 & 0,1 & 0,1 & 18,4 & małe & akcpetowalne \\
\hline 7 & 1 & 0,1 & 0,1 & 3,4 & pomijalne & akcpetowalne \\
\hline 8 & 6 & 5 & 5 & 38 & istotne & tolerowane \\
\hline 9 & 0,1 & 0,1 & 0,1 & 0,7 & małe & akcpetowalne \\
\hline 10 & 0,1 & 0,1 & 0,1 & 0,7 & małe & akcpetowalne \\
\hline 11 & 0,1 & 0,1 & 0,1 & 0,7 & małe & akcpetowalne \\
\hline 12 & 1 & 0,1 & 0,1 & 3,4 & pomijalne & akcpetowalne \\
\hline 13 & 3 & 1 & 0,1 & 11,2 & małe & akcpetowalne \\
\hline 14 & 3 & 0,1 & 0,1 & 9,4 & pomijalne & akcpetowalne \\
\hline 15 & 6 & 1 & 0,1 & 20,2 & małe & akcpetowalne \\
\hline 16 & 6 & 5 & 0,1 & 28,2 & istotne & tolerowane \\
\hline 17 & 0,1 & 0,1 & 1 & 2,5 & pomijalne & akcpetowalne \\
\hline 18 & 3 & 0,1 & 0,1 & 9,4 & pomijalne & akcpetowalne \\
\hline
\end{tabular}


Wśród zdefiniowanych zagrożeń trzy osiągnęły poziom ryzyka określany jako istotny, osiem jako pomijalny oraz siedem jako mały. Po kategoryzacji ryzyka uzyskano wyniki: trzy zagrożenia mieszczą się w kategorii „tolerowane” - należy podejmować działania zapobiegawcze, które prowadzić będą do usunięcia źródeł zagrożeń lub do redukcji ryzyka, natomiast 15 zagrożeń mieści się w kategorii „akceptowalne” - nie ma konieczności podejmowania działań zmniejszających ryzyko, ale należy nadal kontrolować jego poziom. Żadne z rozpoznanych zagrożeń nie osiągnęło poziomu nieakceptowalnego. W przypadku takiego poziomu nie należy dopuszczać do funkcjonowania analizowanego systemu. Oszacowane wartości ryzyka są niewielkie ze względu na wielkości strat wyrażone w złotówkach, które w przypadku bezzałogowych statków powietrznych nie będą wysokie [4].

\section{Podsumowanie i wnioski}

Rekreacyjne loty bezzałogowymi statkami powietrznymi często odbywają się w przestrzeni powietrznej nad obszarem miejskim. $Z$ tego powodu generowanych jest wiele zagrożeń związanych ze środowiskiem, strukturą przestrzeni powietrznej, ograniczeniami prawnymi, gęstością zaludnienia, a także osobą operatora oraz eksploatowanym bezzałogowym statkiem powietrznym. Ze względu na brak egzekwowania istniejących przepisów oraz łatwość dostępu do BSP obszar ten jest szczególnie narażony na występowanie zagrożeń. W badanym obszarze analiz opracowano listę 72 pytań o źródła zagrożenia, z czego rozpoznano 45 źródeł zagrożeń. $\mathrm{Na}$ ich podstawie zidentyfikowano 18 zagrożeń. W dalszych pracach należy opracować model postępowania wobec ryzyka. Należy określić sposoby reagowania na zagrożenia, prowadzące do zmniejszenia poziomu ryzyka. Opracowane sposoby należy zgłaszać do odpowiednich organów państwowych, np. do Urzędu Lotnictwa Cywilnego w celu ich jak najszerszego propagowania. Ze względu na rosnące zainteresowanie niekomercyjnym wykorzystaniem BSP zarówno w lotach VLOS, jak i BVLOS, celowe staje się rozszerzenie analiz na inne cele i obszary operacji bezzałogowych. Kierując się ideami i dobrymi praktykami lotnictwa załogowego, należy doprowadzić do ujednolicenia unormowań prawnych dotyczących zarządzania bezpieczeństwem w lotach bezzałogowych. 


\section{Literatura}

1. Chruzik K., Fellner A.: Zarządzanie ryzykiem w transporcie. Logistyka, 4, 2015, 73117320.

2. Cieślak E.: Bezpieczeństwo w lotnictwie. Bezpieczeństwo i niezawodność w lotnictwie, Toruń 2009.

3. Fellner A., Osowski M.: Uwzględnienie czynnika ludzkiego w analizie bezpieczeństwa procesu zarządzania zasobami ludzkimi. Problemy kryminalistyki, 290(4), 2015.

4. Galant M.: Ograniczanie ryzyka zagrożeń w lotnictwie ogólnym przez zastosowanie systemu monitorującego stan psychofizyczny pilota. Rozprawa doktorska, Poznań 2017.

5. Gill A.: Koncepcja systemu bezpieczeństwa dla wybranych zagrożeń w komunikacji tramwajowej, Technika Transportu Szynowego, nr 10/2013.

6. Grochowski M.: Wnioski z badań zdarzeń lotniczych prowadzonych przez Komisję Badania Wypadków Lotniczych Lotnictwa Państwowego. Bezpieczeństwo i niezawodność w lotnictwie, Toruń 2009.

7. International Civil Aviation Organization: Podręcznik Zarządzania Bezpieczeństwem, Wyd. Urząd Lotnictwa Cywilnego, Warszawa 2009.

8. International Civil Aviation Organization: Safety Management Manual, Doc. 9859 ICAO, Wyd. Urząd Lotnictwa Cywilnego, Warszawa 2013.

9. Kadziński A.: Studium wybranych aspektów niezawodności systemów oraz obiektów pojazdów szynowych. Wydawnictwo Politechniki Poznańskiej, Poznań 2013.

10. Klich E.: Bezpieczeństwo lotów, Radom 2011.

11. Koradecka D.: Bezpieczeństwo i ergonomia pracy. Tom 2, Wydawnictwo CIOP, Warszawa 1999.

12. Krystek R. (red.): Zintegrowany System Bezpieczeństwa Transportu. Tom III. Koncepcja zintegrowanego systemu bezpieczeństwa transportu w Polsce. Politechnika Gdańska, WKŁ, Warszawa 2010.

13. Makarowski R., Smolicz T.: Czynnik ludzki w wypadkach lotniczych. Wyd. Adriana Aviation sp. z o.o., Kosowizna 2012.

14. Merkisz J., Galant M., Karpiński D.: Szacowanie i ocena ryzyka podczas lotu szybowca w kręgu nadlotniskowym. Logistyka, nr 4, 2014.

15. Merkisz J., Galant M.: Ocena ryzyka zagrożeń na trasie Ławica-Kobylnica-Bednary. Journal of KONBiN 2(22) 2012.

16. Polska Agencja Żeglugi Powietrznej: AIP Polska, Warszawa 2017.

17. Romanowska-Słomka I., Słomka A.: Zarządzanie ryzykiem zawodowym. Wydawnictwo Tarbonus, Tarnobrzeg 2005.

18. Tkacz M.: Drony - aspekt prawny i konsekwencje prawne z punktu widzenia policji. Materiały konferencyjne, Konferencja Bezpieczeństwa w Lotnictwie Cywilnym, Warszawa 2018.

19. Urząd Lotnictwa Cywilnego: Krajowy Plan Bezpieczeństwa 2017-2020, Warszawa, 2017.

20. www.pansa.pl 